\title{
Redescriptions of Ordalonema faciepilosa, Peltonotellus melichari and $P$. raniformis, with a key to Western Palaearctic genera of Caliscelidae (Hemiptera: Fulgoromorpha)
}

\author{
WERNER E. HOLZINGER \\ Ökoteam - Institute for Faunistics and Animal Ecology, Bergmanngasse 22, A-8010 Graz, Austria; e-mail: holzinger@oekoteam.at
}

Key words. Fulgoromorpha, Caliscelidae, Peltonotellus, Aphelonema, Ordalonema, redescription, key

\begin{abstract}
First descriptions of males of Peltonotellus raniformis (Mulsant \& Rey, 1855), P. melichari Horváth, 1897 and Ordalonema faciepilosa Dlabola, 1980 are given. In addition, identification keys to the eight Caliscelidae genera of the Western Palaearctic and to the five Peltonotellus Puton, 1886 species of Europe are presented.
\end{abstract}

\section{INTRODUCTION}

The Caliscelidae have been treated as a subfamily of the Issidae until recently. Due to the morphology of their head and ovipositor, Emeljanov (1999) placed them as a separate family within the issid family group (= Issidae $\mathrm{s}$. str., Caliscelidae, Acanaloniidae, Nogodinidae). This opinion has been supported by several authors (e.g. Gnezdilov, 2003a, b; Gnezdilov \& Wilson, 2006; Holzinger et al., 2003; Tishechkin, 2003; Yang \& Chang, 2000), although only diagnostic characters but no autapomorphies have been found to characterize the family (see Gnezdilov \& Wilson, 2006). Caliscelidae is distributed world-wide, containing about 38 genera and 170 species. It is divided in two subfamilies, namely Caliscelinae Amyot \& Serville, 1843 with a single tribe, and Ommatidiotinae Fieber, 1875 with four tribes, Ommatidiotini Fieber, 1875, Coinquendini Gnezdilov \& Wilson, 2006, Augilini Baker, 1915 and Adenissini Dlabola, 1980 (Gnezdilov \& Wilson, 2006).

In the western Palaearctic, about 8 genera and 33 species of the tribes Caliscelini and Ommatidiotini are present. Only one species, Ommatidiotus dissimilis (Fallén, 1806), is distributed throughout central and northern Europe, all others are restricted to the southern parts of the Western Palaearctic realm. They usually live in open habitats - mainly in steppe biotopes, a few species also in marshes, swamps and peat bogs - and feed on various grasses. Many species show distinct sexual dimorphism and have wing polymorphism with a dominance of flightless short-winged morphs.

Despite their usually very conspicuous habitus and coloration, identification of caliscelid planthoppers is a tedious task due to the lack of sufficient descriptions. Below, a key for the identification of western Palaearctic Caliscelidae genera is given. In addition, descriptions of three formerly insuffiently described species, namely Peltonotellus raniformis, $P$. melichari and Ordalonema faciepilosa, and a key to Peltonotellus species are given.

\section{MATERIAL}

Specimens from the collections of the Natural History Museums (NHM) of Budapest, Paris and Vienna, from the Museum für Naturkunde Stuttgart, from coll. Prof. R. Remane, University of Marburg/Lahn and from the Ökoteam - Institute for Faunistics and Animal Ecology, Graz were studied.

Origin of the specimes figured:

Homocnemia albovittata: Greece, Code ÖYUG 75-35, R. Remane leg., in coll. Remane.

Ordalonema faciepilosa: Spain, Catalonia, Muntanya de Sant Mamet, Figuerola de Meià, $700 \mathrm{~m}$, A. Orosz leg., in coll. HNHM Budapest (males), and Spain, Catalonia, Puerto de Ordal $25 \mathrm{~km} \mathrm{~W}$ Barcelona, F. Heller leg., in coll. Staatliches Museum für Naturkunde, Stuttgart (SMNS) [females (paratypes)].

Peltonotellus punctifrons: Serbia, Pirot, Horváth, Sept. 1902, in coll. HNHM, Budapest.

Peltonotellus melichari: Triest, Graeffe (genitalia) and Dalmatia, Horváth, Zelenika, viii.1906, both in coll. HNHM, Budapest, resp. Slovenia, SW Kozina, 3.vi.1999, W. Holzinger leg., in coll. Ökoteam.

Peltonotellus raniformis: M. Vesubie (male) and Mt. Rajek (female) [?; hardly legible], in coll. Ribaut, MNHM, Paris.

Peltonotellus quadrivittatus: Croatia, Mt. Velebit, Sveti Jurai, 6.-9.viii.1999, leg. A. Podlussány, in coll. HNHM, Budapest.

\section{Western Palaearctic genera of Caliscelidae}

\section{Subfamily Ommatidiotinae}

Genus Ommatidiotus Spinola, 1839 (type species: Issus dissimilis Fallén, 1806, by monotypy; ca. 9 species in Palaearctic).

Genus Alloscelis Kusnezov, 1930 (type species: Hysteropterum vittifrons Ivanoff, 1885 , by original designation; monotypic genus; Ukraine, Russia, Caucasus).

Subfamily Caliscelinae

Genus Caliscelis de Laporte, 1833 (type species: C. heterodoxa de Laporte, 1833, by monotypy; syn. C. bonellii Latreille, 1807; ca. 14 species in Palaearctic, one introduced to North America).

Genus Bruchoscelis Melichar, 1906 (type species: Caliscelis peculiaris Horváth, 1904, by monotypy; monotypic genus; Turkey, Palestine). 

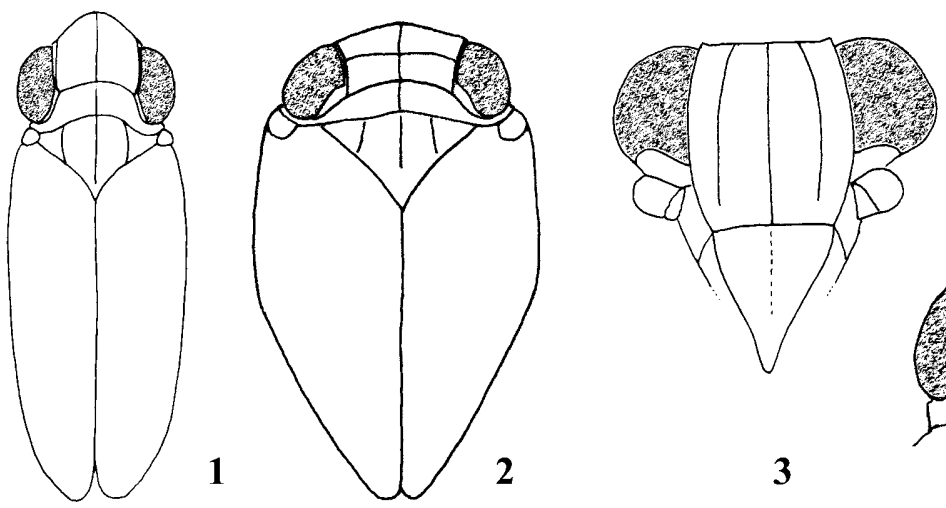

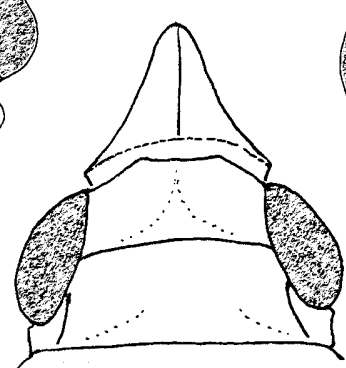

4

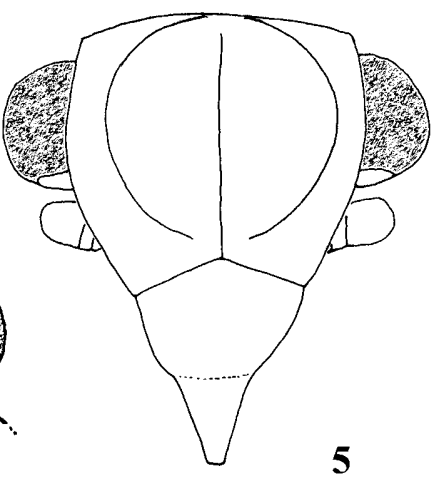

5

Figs 1-5. 1 -Ommatidiotus sp., habitus, dorsal view; 2 - Alloscelis vittifrons, habitus, dorsal view (redrawn after Logvinenko, 1975); 3 - Ordalonema faciepilosa, face, frontal view; 4 - Homaloplasis aprica, head of male, dorsal view (redrawn after Dlabola, 1983); 5 - Peltonotellus sp., face, frontal view.

Genus Homaloplasis Melichar, 1906 (type species: H. aprica Melichar, 1906, by monotypy; monotypic genus; North Africa).

Genus Peltonotellus Puton, 1886 (type species: Peltonotus raniformis Mulsant \& Rey, 1855, by monotypy; five species in Western Palaearctic).

Genus Homocnemia Costa, 1857 (type species: H. albovittata Costa, 1857, by monotypy; Italy, Greece; a second species, $H$. pasagarda Dlabola, 1982 is known from Iran).

Genus Ordalonema Dlabola, 1980 (type species: O. faciepilosa Dlabola, 1980, by original designation; monotypic genus; Spain).

\section{Key to genera}

Note: Taxa known only from the steppe regions of Asia (Kazakhstan, Uzbekistan, Iran etc.) are excluded (e.g. Ahomocnemiella chivensis Kusnezov 1929, Chirodisca astyages Dlabola, 1982 and several species of Aphelonema/Peltonotellus).

1 Fore wings covering abdomen (Ommatidiotinae)....... 2

- Fore wings short, leaving the major part of the abdomen uncovered (Caliscelinae) . . . . . . . . . . . . . 3

2 Body long and slender (Fig. 1).......... Ommatidiotus

- Body short and stout (Fig. 2). . . . . . . . . . . . . . Alloscelis

3 Femora and tibiae of fore legs strongly flattened, leaf-like... $\ldots \ldots \ldots \ldots \ldots \ldots \ldots$ Caliscelis

- Fore legs not or only slightly flattened............ 4

4 Head strongly produced forwards, either snout-shaped or

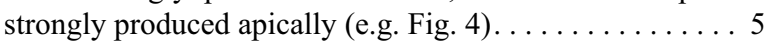

- Frons more or less vertical (males) or slightly produced (some females; Fig. 9). . . . . . . . . . . . . . . 6

5 Femora and tibiae of fore legs slightly flattened. Head snout-shaped.................. Bruchoscelis

- Fore legs not flattened. Frons strongly produced apically (Fig. 4)........................ Homaloplasis

6 Sublateral keels of frons distinctly curved (almost semicircular; Fig. 5). Dorsum with at least 4 longitudinal black stripes. .................... Peltonotellus

- Sublateral keels of frons, if visible, only slightly curved (Fig. 3). Coloration different. ................ 7

7 Males with a unique black and white coloration (Figs 6, 7), females straw-colored, dotted blackish. Head of females produced (Figs 8, 9). . . . . . . . . . . Homocnemia

- Males brownish-greyish, female straw-colored, abdomen in both sexes with dark longitudinal stripes (Figs 29-30). Head of females not produced. . . . . . . . . . . . . Ordalonema

\section{Genus Peltonotellus Puton, 1886}

Peltonotellus Puton, 1886 (replacement name for Peltonotus Mulsant \& Rey, 1855; praeoccupied by Peltonotus Burmeister, 1847, Coleoptera: Scarabaeidae).

Mushya Kato, 1933 (type species M. quadrivittata Kato, 1933 nec Fieber, 1876); synonymized by Chan \& Yang (1994).

Type species: Peltonotus raniformis Mulsant \& Rey, 1855, by monotypy.

Peltonotellus Puton, 1886 is treated either as subgenus of the nearctic genus Aphelonema Uhler, 1876 (see Emeljanov, 1996) or as separate genus (e.g. Holzinger et al., 2003). All species are small (body length $2-4 \mathrm{~mm}$ ), flightless inhabitants of steppe biotopes, feeding on grasses. Up to now, eleven species from the mediterranean and steppe regions of the Palaearctic realm are known. The diversity hot-spot is the steppe of Central Asia; at least six species $-P$. deserticola (Emeljanov, 1964), P. eoa (Kuznezov, 1930), P. oxyura (Kusnezov, 1930), P. registanicus Dlabola, 1961, P. scurrilis (Stål, 1862) and $P$. zonatus Dlabola, 1961 - live there. In Europe, five species are present: $P$. punctifrons is occuring from the the steppe regions of eastern Europe to the eastern Mediterranean realm. $P$. quadrivittatus and $P$. melichari are distributed mainly on the Balkan peninsula, $P$. ellisi is restricted to Corse and $P$. raniformis in known only from Southeastern France and Liguria (Italy).

\section{Key to Peltonotellus species of Europe}

1 Four black longitudinal stripes on the abdomen (Figs 16-18).

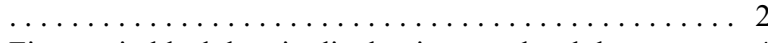
Five or six black longitudinal stripes on the abdomen. ... . 4

2 Frons with two dark longitudinal stripes, in dark specimens extending over the entire frons except for the keels (Fig. 15). Apical lobes of aedeagus longer than basal part (Fig. 25). Ventral margin of male genital style strongly and evenly rounded (Fig. 26)............ P. quadrivittatus

- Frons with four dark spots: two large, almost circular spots in the middle, and two smaller, triangular or elongate spots at the upper margin (Figs 11, 13). Apical lobes of aedeagus shorter than basal part (Figs 21, 23) . . . . . . . . . 3

3 Vertex with two longitudinal dark spots (Fig. 12). Keel between dark spot on vertex and dark stripe of gena light (arrow in Fig. 12). Genital styles in male slender (Fig. 22)... 


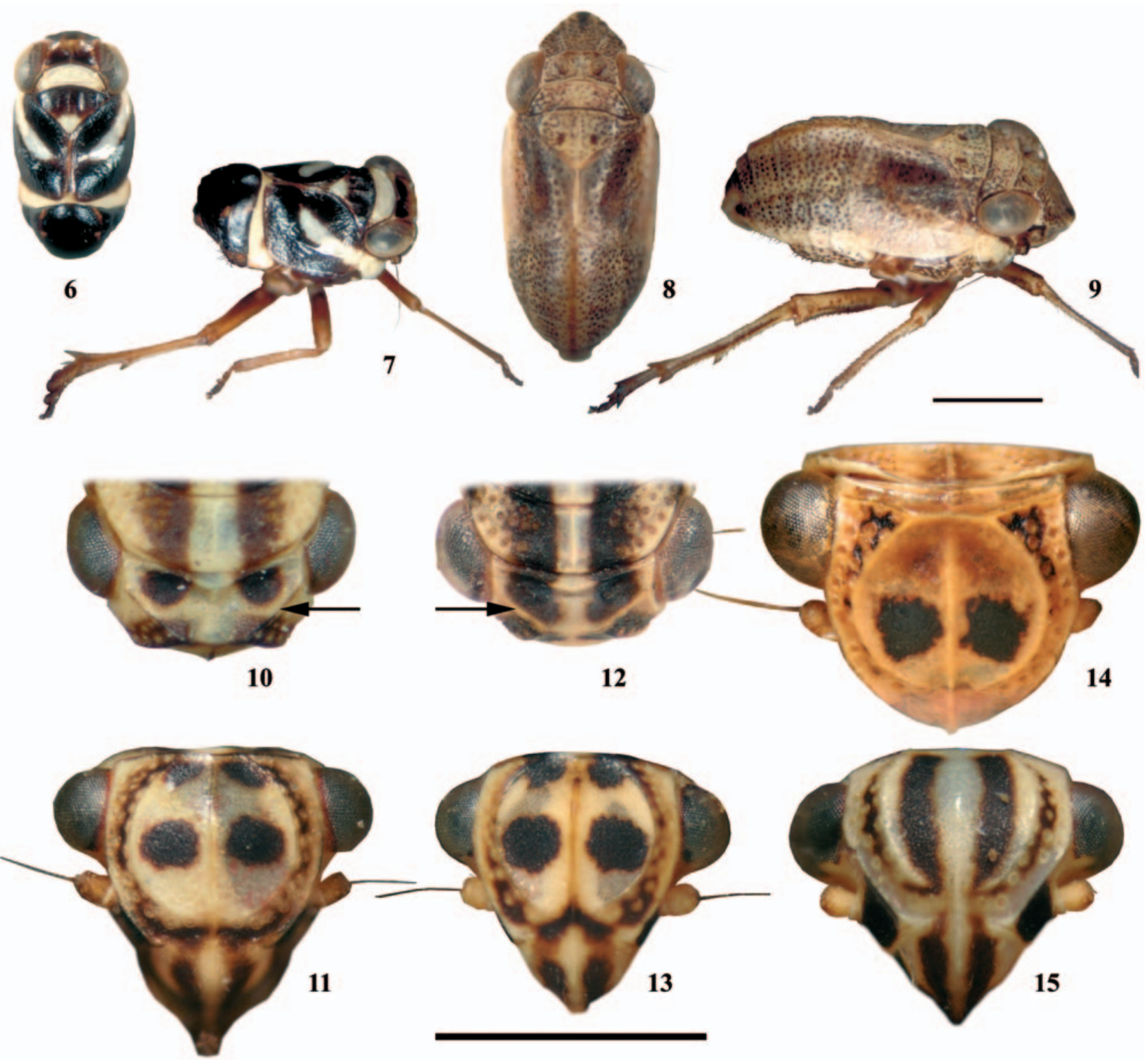

Figs 6-15. 6 and 7 - Homocnemia albovittata, male, dorsal and dorsolateral view; 8 and 9 - Homocnemia albovittata, female, dorsal and dorsolateral view; 10 and 11 - Peltonotellus punctifrons, head and pronotum, dorsal view; head, frontal view; 12 and $13-$ Peltonotellus melichari, head and pronotum, dorsal view; head, frontal view; 14 - Peltonotellus raniformis, head, apical view; 15 Peltonotellus quadrivittatus, head, frontal view. Scale bar $=1 \mathrm{~mm}$.

- Vertex with four dark spots: two larger roundish spots at the hind margin of the vertex, attached to the longitudinal stripes of the pronotum, and two smaller triangular spots at the fore margin. Keel between dark spot on vertex and dark stripe of gena dark (Fig. 10). Genital styles in male with bulbous widening ventrally (Fig. 24)........ P. punctifrons

4 Five black longitudinal stripes on the abdomen..... P. ellisi

- Six black longitudinal stripes on the abdomen (Fig. 20).... . ............................ raniformis

\section{Peltonotellus ellisi (Dlabola, 1974)}

Aphelonema ellisi Dlabola, 1974 : 294.

Peltonotellus ellisi (Dlabola, 1974), new combination by Holzinger et al. (2003).

Diagnosis. The only species with five black stripes on the abdomen. Description of male genitalia is given by Dlabola (1974: 295).
Note. Species not studied.

Distribution. Locus typicus: Vizzavona (Corse, France) ("Korsika - Vizzavona, 1100-1200 m"). Recorded only from Corse, probably endemic (Dlabola, 1974).

\section{Peltonotellus melichari Horváth, 1897}

Peltonotellus melichari Horváth, 1897: 89, new name for Peltonotus quadrivittatus Melichar, 1896 nec Fieber, 1876.

Diagnosis. Four black stripes on the abdomen, frons with four dark spots (in dark specimens sometimes confluent), vertex with two longitudinal spots. See Figs 12, 13, 17, 21, 22. Descriptions of the habitus are given by Horváth (1897: 89 f.), Melichar (1896: 36 f. and Plate 3, sub P. quadrivittatus), Melichar (1906: 31) and Haupt (1935: 127); habitus and genitalia are presented by Holzinger et al. (2003: 436, sub P. punctifrons). 

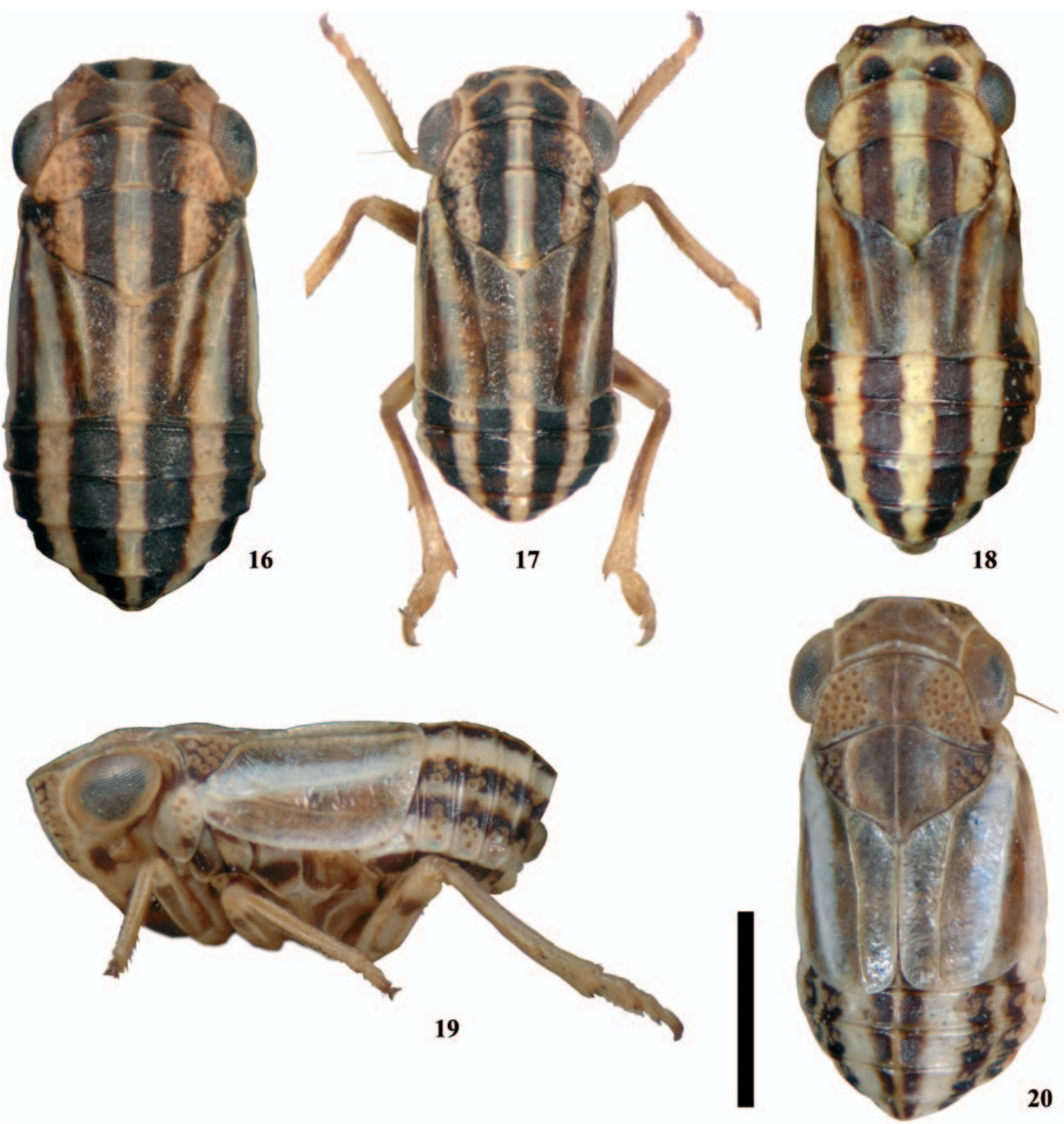

Figs 16-20. 16 - Peltonotellus quadrivittatus, habitus, dorsal view; 17 - Peltonotellus melichari, habitus, dorsal view; 18 - Peltonotellus punctifrons, habitus, dorsal view; 19-20 - Peltonotellus raniformis, habitus, lateral and dorsal view. Scale bar $=1 \mathrm{~mm}$.

Note. Holzinger et al. (2003) erroneosly placed P. melichari Horváth, 1897 - with question mark - in synonymy with $P$. punctifrons Horváth, 1895.

Distribution. Locus typicus: Monfalcone (Friuli - Venetia Giulia, Italy) and Dubrovnik (Croatia) [“Autriche méridionale (Monfalcone)" and "Dalmatie (Ragusa)"]. Northeastern Italy (Friuli-Venetia Giulia; Melichar, 1896, 1906), Slovenia (Holzinger \& Seljak 2001), Croatia (Jankovic, 1984), BosniaHercegovina (Neretva-valley, 25. \& 31.v.2002, leg. Gy. \& I. Rozner, in coll. HNHM Budapest), Serbia (Jankovic, 1984), Makedonia (Jankovic, 1984) and Bulgaria (Emeljanov et al., 2002). The only record from Turkey (Anatolia: "Ankara Baraj, Beynam", Dlabola, 1957) presumably refers to P. punctifrons.

\section{Peltonotellus punctifrons Horváth, 1895}

Peltonotellus punctifrons Horváth, 1895: 162.

Diagnosis. Four black stripes on the abdomen, frons with four dark spots (in dark specimens sometimes confluent), vertex also with four dark spots. See Figs 10, 11, 18, 23, 24. Habitus descriptions are given by Horváth (1895: 162 f., 1897: 90), Melichar (1906: 31 f.), Emeljanov (1964: 444) and Holzinger et al. (2003: 611); habitus and genitalia are figured in Logvinenko (1975: 209).

Note. Fig. 238 B in Holzinger et al. (2003) refers to $P$. melichari. 

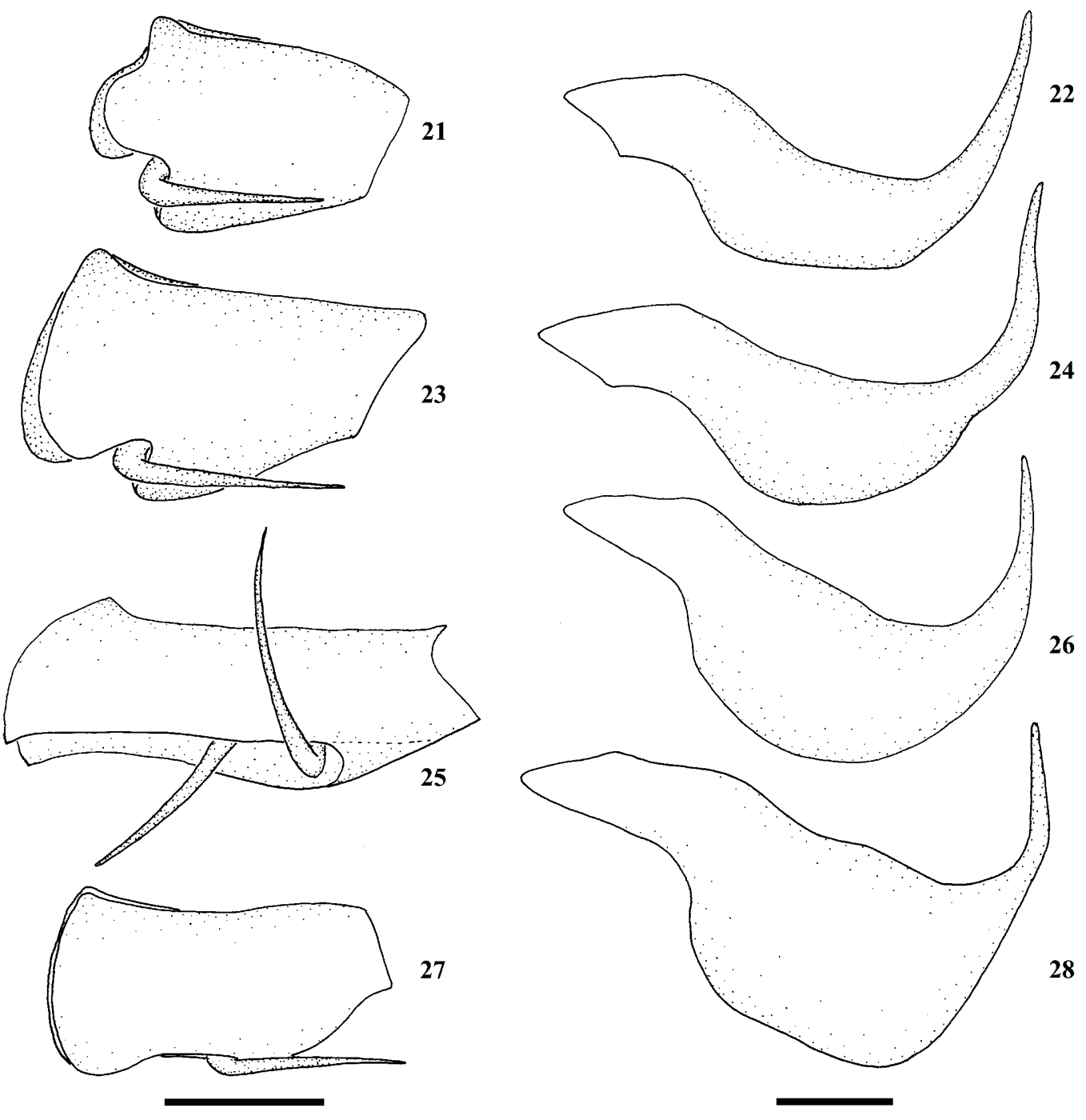

Figs 21-28. 21-22 - Peltonotellus melichari, aedeagus, lateral view, and male genital style, ventrolateral view; 23-24 - Peltonotellus punctifrons, aedeagus, lateral view, and male genital style, ventrolateral view; 25-26-Peltonotellus quadrivittatus, aedeagus, lateral view, and male genital style, ventrolateral view; 27-28 - Peltonotellus raniformis, aedeagus, lateral view, and male genital style, ventrolateral view. Scale bar $=0.1 \mathrm{~mm}$.

Distribution. Locus typicus: Grebenac (Bela Crkva, $30 \mathrm{~km}$ W Beograd, Serbia) ("Hungaria meridionalis: Grebenacz"). Serbia (Horváth, 1895; Melichar, 1906), Croatia (Jankovic, 1984), Makedonia (Jankovic, 1984), Greece (Drosopoulos, 1990), southern Ukraine (from the Black Sea coast to Harkov in the North, to the Kaukasus and Altai mountains in the Eeast; Logvinenko, 1975), Southern Russia (Melichar, 1906; Gnezdilov, 2000), Turkey (Demir, 2006), Kazakhstan (Mitjaev, 1971).

\section{Peltonotellus quadrivittatus (Fieber, 1876)}

Peltonotus quadrivittatus Fieber, 1876: 227.

Peltonotellus quadrivittatus (Fieber, 1876), new combination by Puton, 1886.

Diagnosis. Four black stripes on the abdomen, frons with two dark longitudinal stripes. See also Figs 15, 16, 25 and 26. Habitus descriptions are given by Fieber (1876: 226 f.), Horváth (1897: 90), Melichar (1906: 30 f.) and Haupt (1935: 127); habitus and male genitalia are figured in Holzinger et al. (2003: 435 f., 610).
Distribution. Locus typicus: Slovenia ("Découvert en Styrie par M. Bernuth"; most probably from Untersteiermark, today Slovenia). Northeastern and Central Italy (Servadei, 1967), Slovenia (Holzinger \& Seljak, 2001), Croatia (Mijet Island, 30.v.2002, Babino Polje, leg. Gy. \& I. Rozner; Mt. Velebit, Sveti Juraj, 6.-9.viii.1999, leg. A. Podlussány, in coll. HNHM Budapest), Albania (Dlabola, 1964), Greece (Drosopoulos, 1990). According to Nast (1972), the species is also recorded from Tadzhikistan.

\section{Peltonotellus raniformis (Mulsant \& Rey, 1855)}

Peltonotus raniformis Mulsant \& Rey, 1855 : 207 (Type species of Peltonotus Mulsant \& Rey).

Peltonotellus raniformis (Mulsant \& Rey, 1855), new combination by Puton, 1886 .

Diagnosis. The only species with six black stripes on the abdomen. Male genital styles with strongest bulbous widening of all european species (Fig. 28). See also Figs $14,19,20,27,28$. Descriptions of the habitus are given by Fieber (1876: 224 f.) and Melichar (1906: 29 f.); Dlabola (1974: 295) figured the male genital style. 

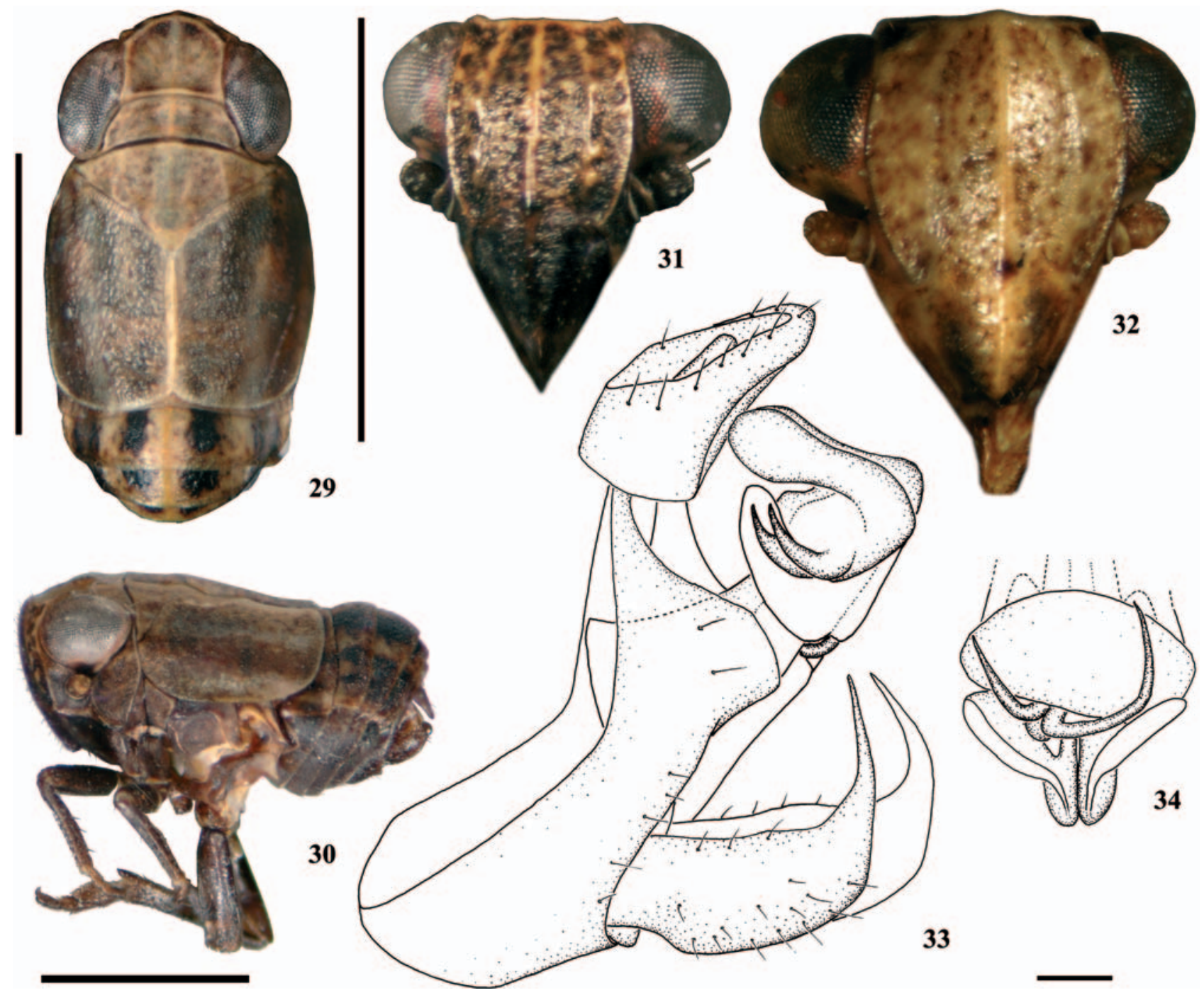

Figs 29-34: Ordalonema faciepilosa. 29 - habitus of male, dorsal view; 30 - habitus of male, lateral view; 31 - face of male, frontal view; 32 - face of female, frontal view; 33 - male genital complex, lateral view; 34 - aedeagus, apical view. Scale bar $=1$ $\mathrm{mm}$ for $29-32,0.1 \mathrm{~mm}$ for 33 and 34 .

Distribution. Locus typicus: Southeastern France ("BassesAlpes", today Alpes-de-Haute-Provence; Melichar, 1906) and adjacent parts of Italy (Liguria; Guglielmino \& Bückle, pers. comm.). The only previous Italian record was published by Ferrari (1885) from Campania. As no other Peltonotellus species was described at that time, and as this species has never been recorded from Central Italy afterwards (A. Guglielmino, C. Bückle and V. D’Urso, pers. comm.), his record most probably refers to $P$. quadrivittatus.

\section{Genus Ordalonema Dlabola, 1980}

Type species: Ordalonema faciepilosa Dlabola, 1980, by original designation.

The genus Ordalonema has been described by Dlabola (1980) to accommodate a single species, O. faciepilosa Dlabola, 1980. The description is based on 14 female specimens collected at Puerto de Ordal near Barcelona, males were unknown. In May 2001, Andras Orosz (HNHM, Budapest) collected five male specimens and one nymph of Ordalonema in two localities 100-150 km northwest of the type locality in the Spanish Pyrenées. As they are very similar to $O$. faciepilosa females in their general morphology, it is very likely that they are conspecific; differences in body coloration and shape of frons (see below) presumably refer to sexual dimorphism.

\section{Supplementary description}

Habitus similar to Peltonotellus species, but head morphology quite different (vertex much longer, sublateral keels only slightly curved; Figs 31, 32), and surface of fore body smooth, without sensory pits (Figs 29, 30). In addition, the aedeagus complex is distinctly different from other Caliscelidae genera, with its apical lobes very long, directed dorsad, and with two long, strongly bent, movable spines (Figs 33, 34).

\section{Ordalonema faciepilosa Dlabola, 1980}

Ordalonema faciepilosa Dlabola, 1980: 2.

\section{Supplementary description}

Body length in males 1.9-2.1 mm, in females 2.4-2.6 mm. Males are distinctively darker than females. The dorsal side of the body is straw-colored, the abdomen bears four longitudinal blackish stripes, the median ones 
smaller than the lateral ones (Figs 29, 30). The ventral side is brownish-black in males and straw-colored in females. In males, the face is dark brown with scattered straw-colored dots (Fig. 31), in females it is straw-colored (Fig. 32). The frons is narrower in males than in females. In both sexes, the median keel of the frons is distinct, while the (slightly curved) sublateral keels vanish ventrally (Figs 3, 31).

Distribution. Locus typicus: Puerto de Ordal $25 \mathrm{~km} \mathrm{~W} \mathrm{Bar-}$ celona (Catalonia, Spain) ("SO-Spanien, Ordal-Pass"). Two additional localities from Spanish Pyrenées: Catalonia, Muntanya de Sant Mamet, Figuerola de Meià, 700 m, 22.-23.v.2001, $3 \delta^{\star}$ and 1 nymph, leg. A.Orosz, and Catalonia, La Noguera Pallaresa, La Baronia de St. Osime, 500 m, 24.v.2001, 20, leg. A. Orosz. The specimens are stored in the Hemiptera collection of the HNHM, Budapest.

ACKNOWLEDGEMENTS. I am grateful to A. Orosz, HNHM, Budapest for his help and advice in planthopper matters, for translation help and for the loan of material, and to $\mathrm{T}$. Vásárhelyi and L. Peregovitz for their support during my stay in Budapest. I want to thank T. Bourgoin, R. Remane, and W. Schawaller for providing material, and V. D'Urso, A. Guglielmino and C. Bückle for valuable data on species distribution. This work was financed by the SYNTHESYS programme (HUTAF) of the EU and is a contribution to the BEFRI project (Biodiversity and Evolution of Fulgoromorpha - a global Research Initiative; see http://bach.snv.jussieu.fr/befri/).

\section{REFERENCES}

Chan M.L. \& Yang C.T. 1994: Issidae of Taiwan (Homoptera: Fulgoroidea). National Chung Hsing University, Department of Entomology, Taichung, Taiwan, 168 pp.

DemIR E. 2006: Preliminary report on the Auchenorrhyncha (Hemiptera) fauna of Kazdaği National Park with two new records for Turkey. Acta Entomol. Sloven. 14(1): 89-102.

Dlabola J. 1957: Results of the zoological expedition of the National Museum in Pragae to Turkey. 20 Homoptera Auchenorrhyncha. Acta Entomol. Mus. Nat. Prag. 31: 19-68.

Dlabola J. 1964: Ergebnisse der Albanien-Expedition 1961 des Deutschen Entomologischen Institutes. Beitr. Entomol. 14: 269-318.

Dlabola J. 1974: Zur Taxonomie und Chorologie einiger mediterraner Zikaden (Homoptera: Auchenorrhyncha). Acta Zool. Acad. Sci. Hung. 20: 289-308.

Dlabola J. 1980: Fünf neue Issiden- und Cicadelliden-Taxa aus Spanien (Homoptera, Auchenorrhyncha). Annot. Zool. Bot. 136: $1-13$.

Drosopoulos S. 1990: The family Issidae (Homoptera, Auchenorrhyncha) in Greece: endemism and speciation. Scopolia (Suppl.) 1: 89-92.

Emeljanov [= Yemel'yanov] A.F. 1964: Suborder Cicadinea (Auchenorrhyncha). In Bei-Bienko G.Ya. (ed.): Keys to the Insects of the European USSR 1. Nauka, Moskva-Leningrad, pp. 421-551.

EMELJanov A.F. 1996: A new genus, Chirodisca gen. n., and new subgenera of the genus Aphelonema Uhl. (Homoptera, Fulgoroidea, Issidae). Entomol. Obozr. 75: 834-835.

EMELJANOv A.F. 1999: Notes on delimitation of families of the Issidae group with description of Caliscelidae belonging to a new genus and tribe (Homoptera, Fulgoroidea). Zoosyst. Ross. 8: $61-72$.
Emeljanov A.F., Gnezdilov V.M. \& Gjonov I.V. 2002: Addenda to the fauna of Cicadina (Hemiptera) of Bulgaria. Acta Entomol. Sloven. 10: 83-90.

FERRARI P.M. 1885: Rincoti Omotteri raccolti nell'Italia centrale e meridionale dal Prof. Cavanna. Boll. Soc. Entomol. Ital. 17: 269-292.

Fieber F.-X. 1876: Les Cicadines d'Europe d'après les originaux et les publications les plus récentes. Deuxième partie: Descriptions des espèces. Rev. Mag. Zool. 1876: 1-258.

GNEZDILOV V.M. 2000: To the knowledge of faunistic complexes of Cicadina (Homoptera) in the main plant formations of the northwestern Caucasus. Entomol. Rev. 80: 927-945.

GNezDilov V.M. 2003a: A new tribe of the family Issidae (Homoptera, Cicadina) with comments on the family as a whole. Zoosyst. Ross. 11: 305-309.

GNezDilov V. M. 2003b: Review of the family Issidae (Homoptera, Cicadina) of the European fauna, with notes on the structure of ovipositor in planthoppers. Chteniya Pamyati N. A. Kholodkovskogo 56: 1-145 [in Russian].

GNezdilov V.M. \& WiLSON M.R. 2006: Systematic notes on tribes in the family Caliscelidae (Hemiptera: Fulgoroidea) with the description of new taxa from Palaearctic and Oriental Regions. Zootaxa 1359: 1-30.

Haupt H. 1935: Unterordnung: Gleichflügler, Homoptera. In Brohmer P., Ehrmann P. \& Ulmer G. (eds): Die Tierwelt Mitteleuropas IV(X). Quelle \& Meyer, Leipzig, pp. 115-262.

Holzinger W.E. \& SelJAK G. 2001: New records of planthoppers and leafhoppers from Slovenia, with a checklist of hitherto recorded species (Hemiptera: Auchenorrhyncha). Acta Entomol. Sloven. 9(1): 39-66.

Holzinger W.E., Kammerlander I. \& Nickel H. 2003: The Auchenorrhyncha of Central Europe. Die Zikaden Mitteleuropas. Fulgoromorpha, Cicadomorpha excl. Cicadellidae. Brill, Leiden-Boston, 673 pp.

Horváth G. 1895: Hemipterères nouveaux d'Europe et des Pays Limitrophes. Rev. Entomol. 14: 152-165.

Horváth G. 1897: Description d'Hémiptères nouveaux et Notes diverses. Rev. Entomol. 16: 81-97.

JANKOVIC L. 1984: Homoptera Auchenorrhyncha (Insecta). Fauna Durmit. 1: 229-282.

Logvinenko V.N. 1975: Fulgoroidni Cikadovi Fulgoroidea. [Fulgoroidea Planthoppers.] Fauna of the Ukraine. Vol. 20/2. Kiev, 288 pp. [in Ukrainian].

Melichar L. 1896: Cicadinen (Hemiptera-Homoptera) von Mittel-Europa. Felix L. Dames, Berlin, 364 pp. +12 plates.

Melichar L. 1906: Monographie der Issiden (Homoptera). Abh. Zool. Bot. Ges. Wien 3(4): 1-327.

MitJAEV I.D. 1971: Leafhoppers of Kazakhstan (HomopteraCicadinea). Nauka, Alma-Ata, 209 pp.

NASt J. 1972: Palaearctic Auchenorrhycha (Homoptera) an Annotated Check List. Polish Academy of Sciences, Warszawa, 550 pp.

Servader A. 1967: Rhynchota (Heteroptera, Homoptera Auchenorrhyncha). Fauna d'Italia 9: 1-851.

TISHECHKIN D. YU. 2003 : Vibrational communication in Cercopoidea and Fulgoroidea (Homoptera, Cicadina) with notes on classification of higher taxa. Russ. Entomol. J. 12: 129-181.

YANG C.-T. \& Chang T.-Y. 2000. The External Male Genitalia of Hemiptera (Homoptera - Heteroptera). Taichung, Shih Way Publishers, 746 pp.

Received August 17, 2006; revised and accepted January 11, 2007 